\section{Unwanted fly in merger ointment}

THE fate of 141-year-old Scientific American, which claims to be the oldest periodical in the United States, hung in the balance earlier this week, after an agreement by the board of Scientific American Inc. to merge with a West German publisher had been confused by a rival bid from Mr Robert Maxwell, the British publisher and owner of Pergamon Press. Mr Maxwell was bidding through the vehicle of the public company, BPPC, in which he holds a controlling interest. It will be for the shareholders in Scientific American Inc., which is not quoted on the stock exchanges, to decide whether to accept the board's proposal or that from Maxwell.

The board's proposal, agreed at a meeting in New York on 30 June, is that the West German company Verlagsgruppe Georg von Holtzbrinck of Stuttgart should be allowed to offer the shareholders of the US company $\$ 258$ for each of their shares, amounting to a total of $\$ 52.6$ million for the company as a whole.

Holtzbrinck's business centres on the publication of the newspaper Handelsblatt, a financial daily, but the company has been since 1981 a partner in the publication of the German edition of Scientific American (under the title Spektrum) and has recently been expanding into the US publishing industry by the acquisition of book-publishing companies.

Under the proposed arrangement, which includes the sale of the book publisher W.H. Freeman Inc., Scientific American would continue to operate as an independent enterprise, with Mr Gerard Piel continuing as chairman of the management board and his son, Mr Jonathan Piel, as editor and publisher. The younger Piel said last week that Holtzbrinck was enthusiastic about his plans for increasing the coverage of news in the magazine.

The present uncertainty is an ironic outcome of a process extending over the past three months, since the impending sale of Scientific American Inc. was first announced, and during which the New York investment (merchant) banker Salomon Brothers was commissioned by the board to conduct a "regulated auction" of the company. This is a process by means of which potential bidders can be screened so as to exclude unwanted owners. Sealed bids were received on 16 June from seven different organizations, including one from Maxwell of $\$ 34$ million.

Even the idea that Scientific American might be put on the block would have seemed strange a short while ago; during the $1960 \mathrm{~s}$, the monthly magazine was among the most successful of internationally circulating publications, both commercially and in reputation. In spite of its antiquity, Scientific American's success is

\section{entirely a post-Second-World-War phe-} nomenon deriving from the acquisition of the title by Gerard Piel and Denis Flanagan, the editor until four years ago.

The need to sell the company has largely arisen because of the discontent of some shareholders. The proportion of shares controlled by Gerard Piel is believed to be about one-sixth, not enough to prevent a sale. The largest shareholder, with 32 per cent, is Mr Arthur Seckler, well known for charitable works.

The company's announcement last week of the agreement with Holtzbrinck said that the board had confirmed this arrangement in spite of the receipt of a letter "from the bidder who had originally offered the lowest price... purporting to raise that offer to $\$ 61$ million".

Although the company says that it has legal grounds for not recommending Maxwell's bid to its shareholders, there is no obvious reason why the shareholders collectively should not let strictly financial considerations determine their decisions. The next step is, apparently, that Holtzbrinck will make a formal offer to buy the shares. A spokesman in Maxwell's office said this week that it would be for the board of Scientific American to consider the BPPC offer in the "light of its fiduciary responsibilities to shareholders"

The uncertainty has nevertheless caused consternation among authors of W.H. Freeman, who appear to be alarmed at the transfer of ownership to Maxwell. Dr Harvey Lodish of the Massachusetts Institute of Technology says that he will not revise the first edition of his successfully published book if the threatened deal goes ahead. Dr Peter Atkins of the University of Oxford, whose successful textbook Physical Chemistry is published in the United States by W.H. Freeman, says that neither the shareholders nor the purchaser should be in doubt that the sale may be that of a "shell" if Freeman authors choose to defect.

Professor Martin Rees (Institute of Astronomy, University of Cambridge), who is writing a book for Freeman but who has not yet signed a contract, says that he is more offended by statements in a circular letter to BPPC shareholders three months ago explaining the basis which the titles of 361 titles of scientific journals were transferred from Pergamon Press to $\mathrm{BPPC}$ in exchange for $£ 240$ million. The circular says that, because scientists are more concerned with quality than price, prices of journals can (and have been) increased "well above the rate of inflation". In 1985 , the prospectus says, the 361 journals will make a profit "before sales commission" of $£ 23.7$ million on a turnover of only $£ 49$ million.

John Maddox

\section{Others have problems too}

Popular science magazines have suffered serious falls in advertising revenue recently from which even the relatively serious Scientific American has not been excepted. According to the US Publishers' Information Bureau, Scientific American's advertising revenues have fallen by 27 per. cent in the past year. The slump in the home computer market is one reason; although corporate advertising partly made up the shortfall, it too fell in the last year. Sales, at around 600,000 copies, are down from a peak of 720,000 in the late 1970 s, mainly because of competition from the more popular magazines.

Mr Gerard Piel, chairman of Scientific American Inc., denies, however, that reduced revenues were the immediate cause of the sale; rather, he blames the "extremely turbulent corporate market" of recent years and the "staggering" frequency of mergers which threatened Scientific American with the possibility of a takeover by an unfriendly bidder who would not uphold the magazine's standards.

Falling advertising revenues are. however, blamed for the demise two weeks ago of Science 86 , the popular publication of the American Association for the Advancement of Science. Time Inc. bought the magazine's assets for $\$ 6$ million and turned the subscriber list over to its own popular magazine Discover, which can use the Science 86 logo for 2 years. Discover has, however, been drifting away in recent months from science towards being a general consumer/ current affairs magazine. Science 86's advertising revenues dropped by 50 per cent in two years. Editorial staff are being "terminated".

Why has there been such a precipitous decline in advertising in popular science magazines? Different people have different answers, but the decline of the home computer market - and competition from specialized home computer magazines - is frequently mentioned. Some advertising agencies believe that readers of such magazines are not sufficiently consumerminded, and that similarly affluent readers can be reached to greater effect in consumer magazines, which are also read by more people per copy. Others point to proliferation of popular science magazines in the early 1980s. But many agree that one more magazine will have to go before equilibrium is reached. The most vulnerable, by common consent, is Science Digest. Its advertising revenues fell by 50 per cent in the past year, and even the wealthy Hearst Corporation is unlikely to continue supporting a loser for ever. Tim Beardsley 